\title{
Population dynamics and community structure of Anopheles mosquitoes along the China-Myanmar border
}

Ying Wang ${ }^{1}$, Daibin Zhong ${ }^{2}$, Liwang Cui ${ }^{3}$, Ming-Chieh Lee ${ }^{2}$, Zhaoqing Yang ${ }^{4}$, Guiyun Yan ${ }^{2}$ and Guofa Zhou ${ }^{2 *}$

\begin{abstract}
Background: Understanding the ecology of malaria vectors such as species composition and population dynamics is essential for developing cost-effective strategies to control mosquito vector populations.

Methods: Adult mosquitoes $(n=79,567)$ were collected in five villages along the China-Myanmar border from April 2012 to September 2014 using the CDC light trap without bait method. Mosquito community structure, Anopheles species composition and diversity were analyzed.

Results: Twenty species of Anopheles mosquitoes were identified, with An. minimus s.l. accounting for $85 \%$ of the total collections. Mosquito densities varied from 0.05 females per trap per night (f/t/n) to $3.00 \mathrm{f} / \mathrm{t} / \mathrm{h}$, with strong seasonality in all sites and densities peaked from June to August. An. minimus s.l. was predominant (accounting for 54-91\% of total captures) in four villages, An. maculatus s.l. was predominant (71\%) in the high elevation village of Dao Nong, and An. culicifacies accounted for $15 \%$ of total captures in the peri-urban area of Simsa Lawk. All 20 species have been captured in the Mung Seng Yang village, 18 and 15 species in Ja Htu Kawng and Na Bang respectively, and nine species in both Simsa Lawk and Dao Nong. Species richness peaked from April to August. Species diversity, species dominance index, and species evenness fluctuated substantially from time to time with no clear seasonality, and varied greatly amongst villages.

Conclusions: Mosquitoes were abundant in the China-Myanmar bordering agricultural area with clear seasonality. Species composition and density were strongly affected by natural environments. The targeted intervention strategy should be developed and implemented so as to achieve cost-effectiveness for malaria control and elimination along the border areas.
\end{abstract}

Keywords: Malaria vector, China-Myanmar border, Population dynamics, Population density, Species richness, Species diversity, Seasonality

\section{Background}

Mosquitoes are vectors of various human and animal infectious diseases [1]. Vector control is an important component and sometimes the only effective way (e.g., for dengue fever) to reduce the transmission of these diseases [1-5]. Understanding the species composition and population dynamics of the local mosquitoes is the crucial step for developing and implementing appropriate strategies to control mosquito vector populations and subsequently the mosquito-borne infectious diseases.

\footnotetext{
* Correspondence: zhoug@uci.edu

${ }^{2}$ Program in Public Health, University of California at Irvine, Irvine, CA, USA Full list of author information is available at the end of the article
}

Malaria is one of the major mosquito-borne diseases endemic to East and Southeast Asia [6-8]. The Greater Mekong Subregion (GMS) is one of the most threatening foci of malaria in Southeast Asia [7-10]. The malaria burden in Myanmar is the heaviest among the GMS nations. More than half of the malaria cases and $\sim 75 \%$ of the malaria deaths in the GMS occurred in Myanmar [11]. International border regions, such as the one shared by China and Myanmar's Kachin State, have the highest malaria incidence and the highest malariarelated mortality rate, at 7.8 deaths/1000 people [11-13]. A large proportion of ethnic minorities live in these remote, often hilly and forested border areas, which are 
prone to malaria transmission by the forest mosquitoes Anopheles minimus s.l. and Anopheles dirus s.l.. The Chinese side of the China-Myanmar border remains a significant foci of clinical malaria despite significant decline of malaria in other parts of China in the past two decades [14, 15].

Effective control of disease vectors requires a good understanding of vector ecology, including vector distribution, development and population dynamics. Recent achievements in malaria control and enthusiasm from international communities have inspired a number of East and Southeast Asian countries such as Thailand and China to redirect program strategies from malaria control towards elimination. There is an increased focus on studying malaria transmission along the ChinaMyanmar border; however, mosquito vector ecology in this area remains almost untouched [16-19]. This lack of information hinders progress toward the goals of eliminating malaria and controlling other mosquitoborne diseases in the area.

The purpose of this study is to acquire critical epidemiological information on vector population ecology by conducting field surveys on vector species composition, species richness, diversity, and population dynamics on both sides of the China-Myanmar border. The results will help to fill important knowledge gaps and aid in developing cost-effective malaria control and elimination strategies in the area.

\section{Methods}

\section{Study sites}

This study was conducted at five sites along the ChinaMyanmar border (Fig. 1). Two of the sites are located in Yingjiang county, Yunnan province, China: Na Bang village, at an elevation of c. $250 \mathrm{~m}$ above sea level (a.s.l.) (range from 240 to $270 \mathrm{~m}$ ), and Dao Nong village, with an elevation of c. $700 \mathrm{~m}$ a.s.l. (range from 660 to $740 \mathrm{~m}$ ). The other three study sites are in the Lai $\mathrm{Za}$ district of Kachin State, Myanmar: Simsa Lawk, representing a peri-urban environment, and Ja Htu Kawng and Mung Seng Yang villages, representing rural settings. All three sites in Myanmar are located in the same valley where $\mathrm{Na}$ Bang town and Lai $\mathrm{Za}$ town are located, at an elevation of c. $250 \mathrm{~m}$ a.s.l. (range from 240 to $280 \mathrm{~m}$ ). All five study sites are surrounded by mountains and comprise either dense forest ( $\mathrm{Na}$ Bang and Simsa Lawk), maize

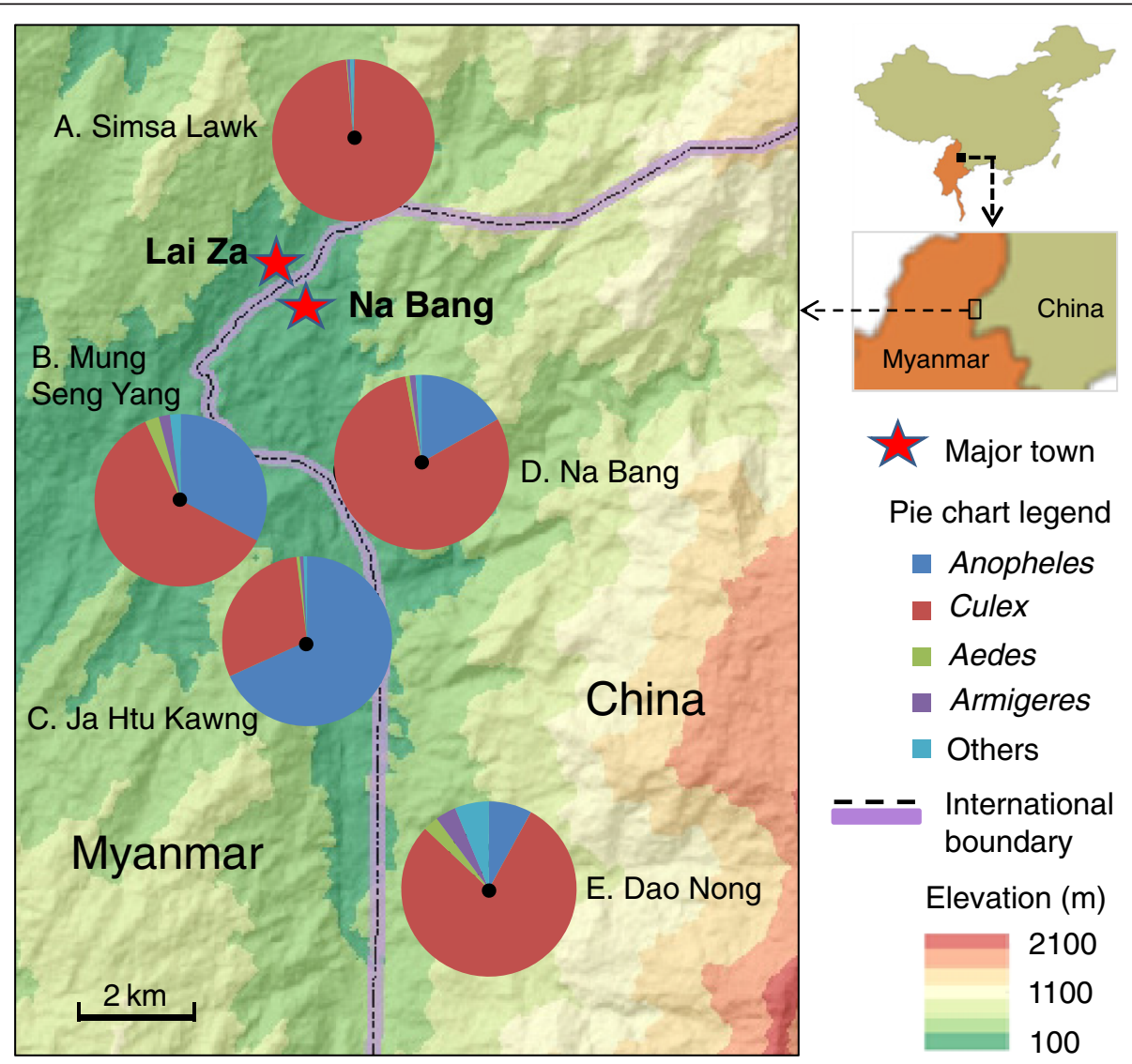

Fig. 1 Locations of the study sites and pie-chart showing mosquito community structure (percentage distribution) along China-Myanmar border. Localities: a Simsa Lawk; b Mung Seng Yang; c Ja Htu Kawng, d Na Bang; and e. Dao Nong 
cultivations on slopes (Ja Htu Kawng and Mung Seng Yang), or white pepper plantations (Dao Nong village). The major habitat type found in all villages was standing water ponds and fish ponds. The area has a subtropical climate, with January through March being relatively dry and cold, and June to August is considered to be the rainy summer season. The annual rainfall is about $1450 \mathrm{~mm}$ with no clear dry season. Annual mean temperature is $21.7^{\circ} \mathrm{C}$, with a low of $15{ }^{\circ} \mathrm{C}$ in January and high of $25^{\circ} \mathrm{C}$ in July. The caught populations totaled 230, 235, and 510 in 2012 in Mung Seng Yang, Ja Htu Kawng, and Simsa Lawk respectively; the populations were 470 and 240 (census includes permanent residents only) in 2012 in $\mathrm{Na}$ Bang and Dao Nong, respectively.

\section{Mosquito collection and species identification}

In the study sites in China, mosquitoes were collected from systematically selected 68 houses in $\mathrm{Na}$ Bang village and all 48 houses in Dao Nong village from April 2012 to April 2013. In Myanmar, mosquitoes were collected from systematically selected 31 houses in Simsa Lawk, from 34 houses in Ja Htu Kawng, and from all 40 houses in Mung Seng Yang, from April 2012 to September 2014. Locations of all sampled houses were determined with a handset global positioning system (Additional file 1: Table S1) (Garmin International Inc., Olathe, KS, USA). Owners of the surveyed houses were requested to sign a freely administered informed consent form covering participation in the study, questionnaire surveys, and monitoring of mosquito population dynamics, i.e., permission to set up the traps and collect mosquitoes. To conduct the sampling, CDC miniature light traps (BioQuip Products, Inc, Rancho Dominguez, CA, USA) without bait were placed in houses at dusk and then collected in the following morning. Traps were placed in the same house for two consecutive nights each sampling occasion. A total of 36 traps were deployed each night. Traps shifted from house to house and from village to village over time so that every house in a given village and every village in the study area has been sampled once (2 nights) every two weeks or two times (4 nights) each month. Once collected, mosquitoes were morphologically separated as Anopheles, Culex, Aedes, and other subfamilies or genera.

Anopheles mosquitoes were further morphologically identified to species or species complex in the field when possible $[20,21]$. Subsample specimen were stored in $-20{ }^{\circ} \mathrm{C}$ freezer immediately after species or species complex was identified and kept frozen until further analysis. The DNA of An. minimus s.l. mosquitoes was extracted from the abdomen of each mosquito for further species confirmation [17]. Anopheles collections from Dao Nong, Na Bang, Ja Htu Kawng, and Mung Seng Yang villages between May 2012 to April 2013 have been used in previous publication [17], the previous stud only published the summary of pooled data of all villages and time frames, and it focused on the role of An. minimus as the malaria vector [17]. In addition to new collections, species diversity, evenness, similarity and their temporal changes were not determined in the previous study. Inter-village heterogeneity, e.g., differences in Anopheles densities, species richness, and diversity, etc. have not been compared.

\section{Data analysis}

Density of mosquitoes was calculated as the number of females per trap per night $(\mathrm{f} / \mathrm{t} / \mathrm{n})$ and monthly average was calculated over all houses in a given village. Pooled Anopheles density was calculated by summing across all Anopheles species. Species richness was measured by the number of species. Species diversity of Anopheles mosquitoes was measured using the Simpson diversity index, $\mathrm{D}$, which can be interpreted as the probability of interspecific encounter, and Shannon-Weiner index, $\mathrm{H}$, which takes into account of individuals of each species [22-25]. The Simpson diversity index is defined as $D=1-\sum_{i=1}^{N} p_{i}^{2}$, where $p_{\mathrm{i}}$ is the fraction of a species which belong to the $\mathrm{i}$-th species, and $\mathrm{N}$ is the number of species. If all species are equally distributed, then the index has its highest value of $[1-(1 / N)]$; if one species is dominant, then the index will approach zero. Other indices calculated included the Berger-Parker dominance index, $d$, evenness index, $E=H$ / $\mathrm{Ln}(\mathrm{S})$, where $\mathrm{H}$ is the Shannon-Weiner diversity index and $\mathrm{S}$ is the total number of species observed at a given village, and the Morista-Hoen similarity index, C [25].

Mosquito abundance data was transformed by the power function $\sqrt[4]{X}$, where $X$ is the monthly density, before comparison and this transformation ensured overall data normality as required for data comparison using analysis such as analysis of variance (ANOVA) and Student $t$-test $[25,26]$. Differences in monthly average mosquito abundance (time series) among different villages were tested using one-way analysis of variance (ANOVA) with repeated measures after data transformation. Pairwise differences in mosquito abundance were compared using the ANOVA post-hoc Tukey-Kramer HSD test or Hsu's MCB test with a significance level of $5 \%$. Statistical analysis was carried out using JMP statistical software (JMP 9.0, SAS Institute Inc., USA).

\section{Results}

Over the study period, a total of 14,786 trap nights were conducted and 79,567 mosquitoes were collected in the five villages. Among the mosquitoes captured, the majority were Culex $(n=62,828$ or $79.0 \%)$, followed by Anopheles ( $n=15,410,19.4 \%)$, Aedes ( $n=466,0.6 \%)$; the remainder belonged to other subfamilies or genera 
(Fig. 1). Twenty Anopheles species have been identified (Table 1), An. minimus s.l. accounted for $84.6 \%$ of total Anopheles collections. All other species accounted less than $5 \%$ of total collections. Thirteen of the 20 Anopheles species each accounted for less than $1 \%$ of total Anopheles collections (Table 1). PCR results $(n=425)$ confirmed that all $A n$. minimus s.l. was $A n$. minimus A.

Anopheles mosquito density varied considerably among study sites (Table 2). Ja Htu Kawng had the highest Anopheles abundance with an average of 3.01 females per trap night $(\mathrm{f} / \mathrm{t} / \mathrm{n})$, which was significantly higher than any other site; followed by Mung Seng Yang $(0.76 \mathrm{f} / \mathrm{t} / \mathrm{n})$ and $\mathrm{Na}$ Bang $(0.42 \mathrm{f} / \mathrm{t} / \mathrm{n})$. The high elevation site of Dao Nong $(0.13 \mathrm{f} / \mathrm{t} / \mathrm{n})$ and the periurban site of Simsa Lawk $(0.05 \mathrm{f} / \mathrm{t} / \mathrm{n})$ and had the lowest mosquito density.

Anopheles mosquito species composition varied considerably among study sites (Tables 1 and 2). Although An. minimus s.l. was dominant in four villages where elevation was low (54-91 \%), An. maculatus s.l. was dominant in the high elevation site of Dao Nong village accounting for $71.3 \%$ of all Anopheles collected (Tables 1 and 2). Other species that accounted for over $10 \%$ in a given study site included An. minimus s.l. (14.7\%) in
Dao Nong, An. maculatus s.l. (13.8 \%) in Na Bang, and An. culicifacies (15.8\%) in Simsa Lawk (Table 1).

$\mathrm{Na}$ Bang had the highest species diversity, with a Simpson diversity index of 0.67 , Shannon-Weiner index of 1.66 and 15 Anopheles species. It also had the highest evenness index (Table 2). Although 18 Anopheles species were detected, Ja Htu Kawng had the lowest species diversity (Simpson 0.18 and Shannon-Weiner 0.50) because $A n$. minimus was so dominant (90.7\%) that other species contributed very little to the diversity, leading to the lowest evenness (Table 2). Despite very similar species diversity in the other three villages (diversity index 0.44-0.48), all 20 Anopheles species were captured in Mung Seng Yang, whereas only nine species were collected in both Dao Nong and Simsa Lawk villages (Table 2). Interestingly, similarity analysis showed that species composition in Dao Nong was significantly dissimilar to the rest of the villages (Morista-Horn indices $<0.43$ ) while the other four villages had very similar species compositions (Morista-Horn indices range from 0.86 to 0.98 ) (Table 3 ).

Anopheles population densities showed clear seasonality in all villages, with peak months from April to

Table 1 Anopheles species composition by village and pooled across study sites and study period

\begin{tabular}{|c|c|c|c|c|c|c|c|}
\hline \multirow[t]{2}{*}{ Species } & \multicolumn{5}{|c|}{ Composition by village } & \multicolumn{2}{|l|}{ Pooled } \\
\hline & DN & NB & JHK & MSY & SSL & $\mathrm{N}$ & $\%$ \\
\hline An. minimus $\mathrm{A}$ & 14.73 & 54.18 & 90.73 & 74.02 & 69.47 & 13,038 & 84.61 \\
\hline An. maculatus s.l. & 71.32 & 13.80 & 0.99 & 4.12 & 9.47 & 530 & 3.44 \\
\hline An. culicifacies s.l. & 5.04 & 5.19 & 2.05 & 4.56 & 15.79 & 437 & 2.84 \\
\hline An. jeyporiensis & 2.33 & 1.01 & 2.02 & 1.04 & 0.53 & 277 & 1.80 \\
\hline An. splendidus & 4.26 & 5.44 & 0.87 & 3.28 & 0.00 & 237 & 1.54 \\
\hline An. vagus & 0.39 & 3.16 & 1.05 & 2.68 & 2.11 & 220 & 1.43 \\
\hline An. sinensis & 0.00 & 3.16 & 0.61 & 2.56 & 0.53 & 161 & 1.04 \\
\hline An. barbirostris s.l. & 0.39 & 6.58 & 0.33 & 1.68 & 0.00 & 133 & 0.86 \\
\hline An. peditaeniatus & 1.16 & 2.66 & 0.25 & 2.96 & 0.00 & 127 & 0.82 \\
\hline An. fluviatilis & 0.00 & 0.00 & 0.73 & 0.24 & 0.00 & 91 & 0.59 \\
\hline An. kochi & 0.00 & 0.76 & 0.20 & 0.36 & 0.53 & 39 & 0.25 \\
\hline An. tessellatus & 0.00 & 2.78 & 0.01 & 0.64 & 0.00 & 39 & 0.25 \\
\hline An. crawfordi & 0.00 & 0.00 & 0.04 & 0.24 & 0.00 & 11 & 0.07 \\
\hline An. lesteri & 0.00 & 0.00 & 0.03 & 0.32 & 0.00 & 11 & 0.07 \\
\hline An. barbumbrosus & 0.39 & 0.00 & 0.01 & 0.32 & 0.00 & 10 & 0.06 \\
\hline An. messeae & 0.00 & 0.63 & 0.01 & 0.12 & 0.00 & 9 & 0.06 \\
\hline An. annularis s.l. & 0.00 & 0.13 & 0.02 & 0.12 & 0.53 & 7 & 0.05 \\
\hline An. stephensi & 0.00 & 0.38 & 0.01 & 0.04 & 1.05 & 7 & 0.05 \\
\hline An. indefinitus & 0.00 & 0.13 & 0.00 & 0.08 & 0.00 & 3 & 0.02 \\
\hline An. gigas & 0.00 & 0.00 & 0.00 & 0.04 & 0.00 & 1 & 0.01 \\
\hline Other Anopheles (unidentified) & 0.00 & 0.00 & 0.06 & 0.60 & 0.00 & 22 & 0.14 \\
\hline
\end{tabular}


Table 2 Population density (Anopheles females/trap/night) and species diversity of Anopheles mosquitoes at each study site

\begin{tabular}{|c|c|c|c|c|c|c|}
\hline \multirow[t]{2}{*}{ Village } & \multirow[t]{2}{*}{ Density $(\mathrm{f} / \mathrm{t} / \mathrm{n})(95 \% \mathrm{Cl})$} & \multirow[t]{2}{*}{ Species richness } & \multicolumn{2}{|c|}{ Diversity index } & \multirow[t]{2}{*}{ Dominance index } & \multirow[t]{2}{*}{ Evennes } \\
\hline & & & Simpson & Shannon & & \\
\hline Ja Htu Kawng & $3.01[2.41,3.60] \mathrm{a}$ & 18 & 0.18 & 0.50 & 0.91 & 0.17 \\
\hline Mung Seng Yang & $0.76[0.16,1.35] \mathrm{b}$ & 20 & 0.44 & 1.16 & 0.74 & 0.39 \\
\hline Na Bang & $0.42[-0.43,1.26] \mathrm{b}$ & 15 & 0.67 & 1.66 & 0.54 & 0.61 \\
\hline Dao Nong & $0.13[-0.74,1.00] \mathrm{b}$ & 9 & 0.46 & 1.01 & 0.71 & 0.46 \\
\hline Simsa Lawk & $0.05[-0.55,0.64] \mathrm{b}$ & 9 & 0.48 & 1.01 & 0.69 & 0.46 \\
\hline
\end{tabular}

Different (same) letter indicating (no) significant difference at $p=0.05$ level, Tukey HSD test of $\sqrt[4]{X}$ transformed data

August each year (Fig. 2a). Anopheles population dynamics differed significantly amongst the study sites (repeated measure ANOVA $\left.F_{4,114}=33.86, P<0.0001\right)$. Ja Htu Kawng had significantly higher densities of Anopheles mosquitoes than the other villages, and differences in average monthly population densities among other villages was not statistically significant (Tukey-Kramer HSD, $\left.\mathrm{q}^{*}=2.77, P<0.05\right)$. Ja Htu Kawng had the highest density of any site in every month surveyed, and the periurban site of Simsa Lawk had more than 60-fold lower Anopheles density than Ja Htu Kawng.

Species richness, measured by the number of Anopheles species trapped, also showed strong seasonality in three study sites, Na Bang, Ja Htu Kawng, and Mung Seng Yang, but varied little in the other two sites (Fig. 2b). The periurban site, Simsa Lawk, and the high elevation site, Dao Nong, had the lowest number of Anopheles species, varying little over time; the other three sites had similar number of species all over the study period (Fig. 2b).

Interestingly, different from population density and species richness, species diversity fluctuated over time but did not show any seasonality in all study sites (Fig. 2c and d). Mung Seng Yang was the only village where species diversity was relatively stable and high in 2013 and 2014 (Fig. 2c and d). Similarly, dominance index and evenness indices varied substantially from time to time (Fig 2e and f). In Ja Htu Kawng and Simsa Lawk, dominance index was sometimes very high, i.e., with one species being dominant (Fig. 2e). In Ja Htu Kawng, dominance index was high most of the time, while evenness index was low in 2013 and 2014 (Fig. 2f).

Table 3 Similarity in species composition between different villages

\begin{tabular}{llllll}
\hline & $\begin{array}{l}\text { Dao } \\
\text { Nong }\end{array}$ & Na Bang & $\begin{array}{l}\text { Ja Htu } \\
\text { Kawng }\end{array}$ & $\begin{array}{l}\text { Mung Seng } \\
\text { Yang }\end{array}$ & Simsa Lawk \\
\hline Dao Nong & 1 & & & & \\
Na Bang & 0.43 & 1 & & & \\
Ja Htu Kawng & 0.21 & 0.86 & 1 & & \\
Mung Seng Yang & 0.26 & 0.94 & 0.98 & 1 & 1 \\
Simsa Lawk & 0.34 & 0.95 & 0.95 & 0.98 & \\
\hline
\end{tabular}

\section{Discussion}

Aside from Africa, Southeast Asia is the key focusing area of malaria transmission because of its intense $P$. vivax transmission and mixed infections. In addition, mosquito vectors show greater species diversity in Southeast Asia than in Africa. For example, in Africa, three Anopheles species, An. gambiae s.s., An. funestus s.l., and An. arabiensis are responsible for almost all malaria transmissions [27-29]. Conversely, there are more than 20 major malaria vector species in Southeast Asia, which makes vector control extremely difficult because of the complex biology and ecology of the different vectors [29-38]. Among the 20 identified Anopheles species in this study, 14 of them have been implicated in malaria transmission in East and Southeast Asia [29-38]. Furthermore, the top four most abundant Anopheles mosquitoes found in this study are all malaria vectors, including one of the key malaria vectors in Southeast Asia, An. minimus s.l., which was also the most abundant Anopheles species in the study area. This species is not exclusively anthropophilic or zoophilic, not exclusively endophagic or exophagic, and not exclusively exophilic or endophilic, therefore, it is extremely difficult to control it with currently available tools [17, 39, 40]. While other countries have implemented intensive vector-borne disease control efforts and have seen a decline in the prevalence of malaria, the malaria situation in Myanmar is largely unknown [6-8]. It is believed that Myanmar is and will remain the key malaria parasite reservoir in Southeast Asia, significantly offsetting the enormous regional efforts for malaria elimination [7-9]. Studies found that the majority of the P. falciparum malaria cases in China were imported from Myanmar [14, 41, 42]. To effectively control malaria in Myanmar and to eliminate malaria in China, it is essential to understand the community structure and species composition, the temporal dynamics, and the spatial distribution of mosquito vectors in this area.

The seasonal fluctuations in vector density and species richness is likely due to the seasonal rainfalls and temperature changes $[43,44]$. Although there is no clear dry season in the study area, summer time (May to August) is usually the rainy season, when temperatures can reach $25-30{ }^{\circ} \mathrm{C}$, which is perfect for malaria 

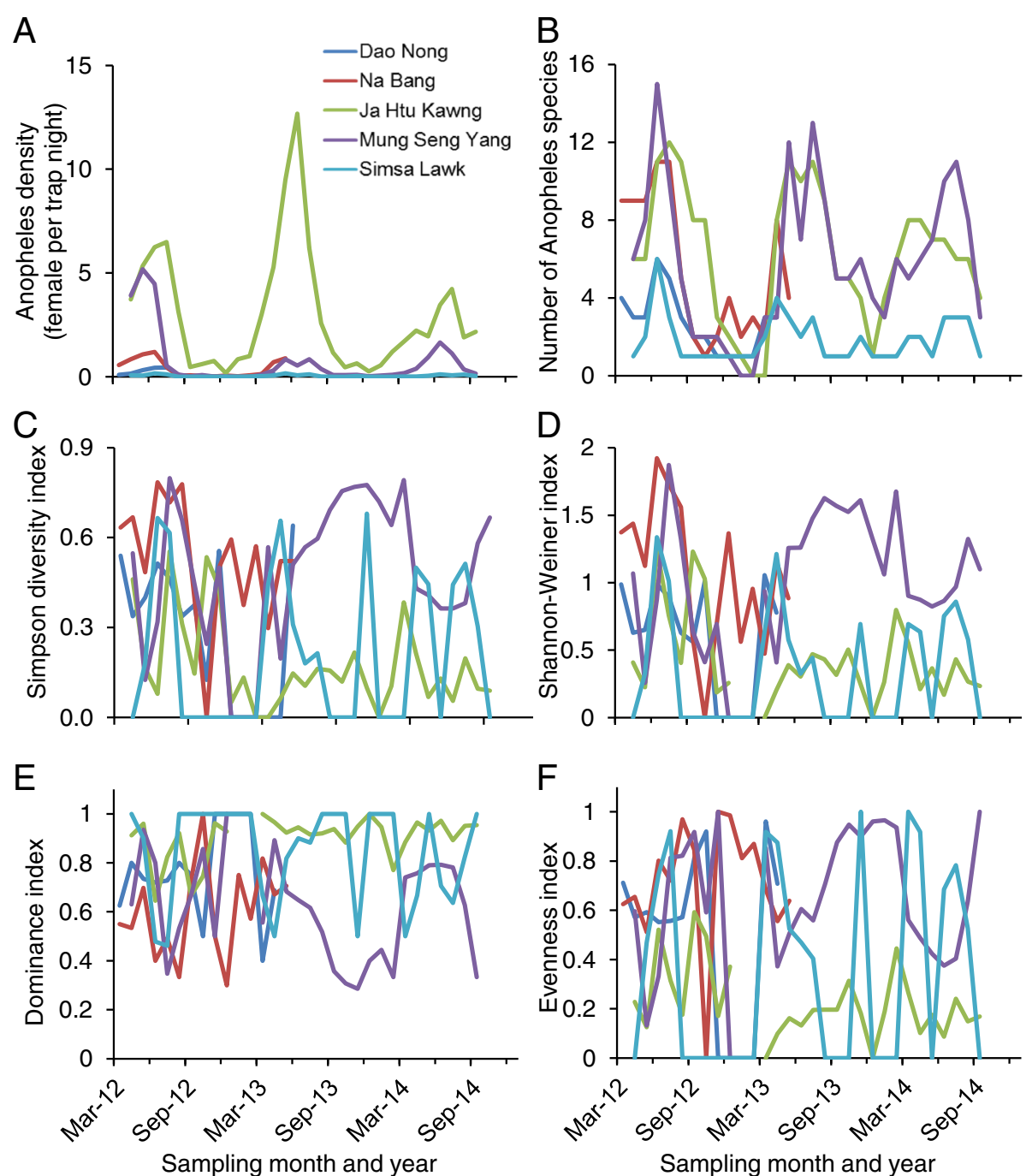

Fig. 2 Population dynamics of Anopheles mosquitoes a population density (females/trap/night) pooled of all Anopheles species, b species richness, c Simpson species diversity, $\mathbf{d}$ Shannon-Weiner diversity index, e dominance index, and $\mathbf{f}$ evenness index in different stud sites

transmission $[44,45]$. Winter is relatively dry and temperatures drop to an average of around $10-15{ }^{\circ} \mathrm{C}$, which is unfavorable to the development of both immature and adult mosquitoes. This climatic-vector interaction is common in Culex, Aedes, and Anopheles mosquitoes, for example, vector population dynamics are strongly associated with climatic conditions, winter diapause or refuge, and water availability affecting mosquito development [46-49]. This seasonality in vector abundance leads to seasonality of vector-borne infectious diseases [41, 42, 45, 49-51].

Differences in vector abundance, community structure, and Anopheles species composition at different sites may be explained by the contextual determinants, mainly environmental factors. There are many water ponds in $\mathrm{Na}$ Bang, Ja Htu Kawng, and Mung Seng Yang villages. Residents in these villages raise a lot of livestock such as pigs and bovines (mainly domestic cattle and water buffalo), providing a perfect environment for Anopheles mosquitoes, especially the zoo-anthropophilic species An. minimus. Larvae of An. sinensis (in $\mathrm{Na}$ Bang) and $A n$. minimus s.l. (in Ja Htu Kawng) were frequently found in these villages (GZ unpublished data). On the other hand, in both Dao Nong and Simsa Lawk villages, abundance of Anopheles was very low. Both villages have heavy forest coverage, although with totally different settings rural in Dao Nong vs. urban in Simsa Lawk, and both have fewer livestock than the other three villages. $A n$. minimus s.l. was dominant in Ja Htu Kawng, but both $\mathrm{Na}$ Bang and Mung Seng Yang had a diverse Anopheles composition. These differences in Anopheles abundance and species composition suggest that micro-environmental factors may play an important role in influencing the occurrence and abundance of these species. 
It is worth mentioning that the result from this study is different from the result of the study conducted in northern Thailand [37], which found that An. minimus s.l. occurs in less disturbed forested area and that deforestation has negative effects on An. minimus s.l. abundance [38]. In our study, An. minimus s.l. was most abundant in deforested areas such as Ja Htu Kawng and Mung Seng Yang villages and it was less abundant in the forested areas such as $\mathrm{Na}$ Bang and Dao Nong. In the Thailand study, breeding habitats were mainly found along streams outside the villages, whereas in this study, habitats were mainly standing water ponds within the village (GZ personal observations), we suspect that the species found in the two studies are different. Unfortunately, the Thailand study did not mention details about the An. minimus s.l. species. Most of the Anopheles mosquitoes caught (97\%) were known malaria vectors, including the key malaria vectors in Southeast Asia $A n$. minimus s.l.. Anopheles sinensis is considered the most common malaria vector in China [32], but it is not common in the study area, perhaps because $A n$. sinensis prefers rice paddies and does not like the forest environment. In addition to inter-villages variations in Anopheles densities and species diversity, there is the potential of intravillage heterogeneity, such as house-to-house variations in Anopheles densities and possible spatial clustering, which is open for further investigation.

\section{Conclusion}

In conclusion, this study provides fundamental information on mosquito abundance and population dynamics in the China-Myanmar border area. The results indicate that both vector abundance and species diversity vary greatly from village to village and from season to season. The knowledge gained from this study will be useful for designing targeted intervention strategies for malaria control in Myanmar and malaria elimination in China.

\section{Additional file}

Additional file 1: GPS readings of all surveyed houses. (XLSX $18 \mathrm{~kb})$

\section{Competing interests}

The authors have declared that they have no competing interests.

\section{Authors' contributions}

GZ, ZY, GY, and LC participated in the development of the protocol. YW and GZ conceived of the study, analysed the data, and wrote the manuscript. $\mathrm{MCL}$ was responsible for data management. All authors read and approved the final manuscript.

\section{Acknowledgements}

We would like to thank the field staff at the Na Bang station for their efforts in assisting with the collection and identification of mosquitoes. We are grateful to the Kachin State government for supporting this study in the area. This study was supported by National Institutes of Health (U19 Al089672) and by Emerging Infectious Disease Prevention and Control Key
Laboratory of Guangdong Provincial Higher Education (KLB09007) and the Military Scientific Research Project of China (CWS12J017).

\section{Author details}

${ }^{1}$ Institute of Tropical Medicine, Third Military Medical University, Chongqing, China. ${ }^{2}$ Program in Public Health, University of California at Irvine, Irvine, CA, USA. ${ }^{3}$ Department of Entomology, Pennsylvania State University, University Park, PA, USA. ${ }^{4}$ Department of Pathogen Biology and Immunology, Kunming Medical University, Kunming, China.

Received: 6 February 2015 Accepted: 26 August 2015

Published online: 04 September 2015

\section{References}

1. World Health Organization. Vector control for malaria and other mosquitoborne disease. Geneva: WHO TRS-857; 1995. http://www.who.int/malaria/ publications/atoz/who_trs_857/en/. Accessed January 15, 2015.

2. Morrison AC, Zielinski-Gutierrez E, Scott TW, Rosenberg R. Defining challenges and proposing solutions for control of the virus vector Aedes aegypti. PLoS Med. 2008;5, e68.

3. mal ERACGOVC. A research agenda for malaria eradication: vector control. PLoS Med. 2011:8:e1000401.

4. van den Hurk AF, Ritchie SA, Mackenzie JS. Ecology and geographical expansion of Japanese encephalitis virus. Annu Rev Entomol. 2009:54:17-35.

5. Tomori O. Yellow fever in Africa: public health impact and prospects for control in the 21st century. Biomedica. 2002;22:178-210.

6. World Health Organization. World malaria report 2012. Geneva: WHO; 2012. http://www.who.int/malaria/publications/world_malaria_report_2012/report/en/. Accessed January 15, 2015.

7. Cui L, Yan G, Sattabongkot J, Cao Y, Chen B, Chen X, et al. Malaria in the Greater Mekong Subregion: heterogeneity and complexity. Acta Trop. 2012;121:227-39.

8. Delacollette C, D'Souza C, Christophel E, Thimasarn K, Abdur R, Bell D, et al. Malaria trends and challenges in the Greater Mekong Subregion. Southeast Asian J Trop Med Public Health. 2009;40:674-91.

9. Gething PW, Elyazar IR, Moyes CL, Smith DL, Battle KE, Guerra CA, et al. A long neglected world malaria map: Plasmodium vivax endemicity in 2010. PLoS Negl Trop Dis. 2012;6, e1814.

10. Battle KE, Gething PW, Elyazar IR, Moyes CL, Sinka ME, Howes RE, et al. The global public health significance of Plasmodium vivax. Adv Parasitol. 2012;80:1-111.

11. World Health Organization. World malaria report 2008. Geneva: WHO; 2008. http://www.who.int/malaria/publications/atoz/9789241563697/en/. Accessed January 15, 2015.

12. World Health Organization. Malaria in the Great Mekong Subregion: Regional and Country Profile. WHO Southeast Asia and Western Pacific Region, India. 2010. http://www.searo.who.int/entity/malaria/documents/ Mekong_pro/en/. Accessed January 15, 2015.

13. World Health Organization. World malaria report 2010. Geneva: WHO; 2010. http:// wuw.who.int/malaria/world malaria report 2010/en/. Accessed January 15, 2015.

14. Xia ZG, Yang MN, Zhou SS. Malaria situation in the People's Republic of China in 2011. Chin J Parasitol Parasitic Dis. 2012;30:419-22 [In Chinese].

15. Lin H, Lu L, Tian L, Zhou S, Wu H, Bi Y, et al. Spatial and temporal distribution of falciparum malaria in China. Malar J. 2009;8:130.

16. Yan J, Li N, Wei X, Li P, Zhao Z, Wang L, et al. Performance of two rapid diagnostic tests for malaria diagnosis at the China-Myanmar border area. Malar J. 2013;12:73

17. Yu G, Yan G, Zhang N, Zhong D, Wang Y, He Z, et al. The Anopheles community and the role of Anopheles minimus on malaria transmission on the China-Myanmar border. Parasit Vectors. 2013;6:264.

18. Zhou X, Li SG, Chen SB, Wang JZ, Xu B, Zhou HJ, et al. Co-infections with Babesia microti and Plasmodium parasites along the China-Myanmar border. Infect Dis Poverty. 2013;2:24.

19. Moore SJ, Min X, Hill N, Jones C, Zaixing Z, Cameron MM. Border malaria in China: knowledge and use of personal protection by minority populations and implications for malaria control: a questionnaire-based survey. BMC Public Health. 2008:8:344.

20. Dong SH. The mosquito fauna of Yunnan, vol. 1. Kunming: Yunnan Publishing Group; 2010. p. 394.

21. Dong SH, Zhou HN, Gong ZD. The mosquito fauna of Yunnan, vol. 2. Kunming: Yunnan Publishing Group; 2010. p. 750.

22. Alatalo R, Alatalo R. Components of diversity: multivariate analysis with interaction. Ecology. 1977;58:900-6. 
23. Norris JL, Pollock KH. Non-parametric MLE for Poisson species abundance models allowing for heterogeneity between species. Environ Ecol Stat. 1998:5:391-402.

24. Kweka EJ, Zhou G, Munga S, Lee MC, Atieli HE, Nyindo M, et al. Anopheline larval habitats seasonality and species distribution: a prerequisite for effective targeted larval habitats control programmes. PLoS One. 2012;7, e52084.

25. Southwood TRE, Henderson PA. Ecological methods. Blackwell science. 2000. p. 575

26. Legendre $P$, Legendre L. Numerical ecology. 2nd ed. Amsterdam: Elsevier; 1998. p. 853

27. Zhou G, Afrane YA, Vardo-Zalik AM, Atieli H, Zhong D, Wamae $P$, et al. Changing patterns of malaria epidemiology between 2002 and 2010 in western Kenya: the fall and rise of malaria. PLoS One. 2011;6, e20318.

28. Sinka ME, Bangs MJ, Manguin S, Rubio-Palis Y, Chareonviriyaphap T, Coetzee M, et al. A global map of dominant malaria vectors. Parasit Vectors. 2012;5:69.

29. Sinka ME, Bangs MJ, Manguin S, Chareonviriyaphap T, Patil AP, Temperley $\mathrm{WH}$, et al. The dominant Anopheles vectors of human malaria in the AsiaPacific region: occurrence data, distribution maps and bionomic precis. Parasit Vectors. 2011;4:89

30. Elyazar IR, Sinka ME, Gething PW, Tarmidzi SN, Surya A, Kusriastuti R, et al. The distribution and bionomics of Anopheles malaria vector mosquitoes in Indonesia. Adv Parasitol. 2013;83:173-266.

31. Alam MS, Khan MG, Chaudhury N, Deloer S, Nazib F, Bangali AM, et al. Prevalence of Anopheline species and their Plasmodium infection status in epidemic-prone border areas of Bangladesh. Malar J. 2010;9:15.

32. Zhu G, Xia H, Zhou H, Li J, Lu F, Cao J, et al. Susceptibility of Anopheles sinensis to Plasmodium vivax in malarial outbreak areas of central China. Parasit Vectors. 2013;6:176.

33. Zollner GE, Ponsa N, Garman GW, Poudel S, Bell JA, Sattabongkot J, et al. Population dynamics of sporogony for Plasmodium vivax parasites from western Thailand developing within three species of colonized Anopheles mosquitoes. Malar J. 2006:5:68.

34. Singh N, Chand SK, Bharti PK, Singh MP, Chand G, Mishra AK, et al. Dynamics of forest malaria transmission in Balaghat district, Madhya Pradesh, India. PLoS One. 2013;8, e73730.

35. Bashar K, Tuno N, Ahmed TU, Howlader AJ. False positivity of circumsporozoite protein (CSP)-ELISA in zoophilic anophelines in Bangladesh. Acta Trop. 2013;125:220-5.

36. Rattanarithikul $\mathrm{R}$, Konishi $\mathrm{E}$, Linthicum KJ. Detection of Plasmodium vivax and Plasmodium falciparum circumsporozoite antigen in anopheline mosquitoes collected in southern Thailand. Am J Trop Med Hyg. 1996;54:114-21.

37. Overgaard HJ, Tsuda Y, Suwonkerd W, Takagi M. Characteristics of Anopheles minimus (Diptera: Culicidae) larval habitats in Northern Thailand. Environ Entomol. 2002;31:134-41.

38. Garros C, Koekemoer LL, Coetzee M, Coosemans M, Manguin S. A single multiplex assay to identify major malaria vectors within the African Anopheles funestus and the Oriental An. minimus groups. Am J Trop Med Hyg. 2004;70:583-90.

39. Chareonviriyaphap T, Bangs MJ, Suwonkerd W, Kongmee M, Corbel V, Ngoen-Klan R. Review of insecticide resistance and behavioral avoidance of vectors of human diseases in Thailand. Parasit Vectors. 2013;6:280. Review.

40. Hii J, Rueda LM. Malaria vectors in the Greater Mekong Subregion: overview of malaria vectors and remaining challenges. Southeast Asian J Trop Med Public Health. 2013;44 Suppl 1:73-165. Review.

41. Li N, Parker DM, Yang Z, Fan Q, Zhou G, Ai G, et al. Risk factors associated with slide positivity among febrile patients in a conflict zone of northeastern Myanmar along the China-Myanmar border. Malar J. 2013;12:361.

42. Zhou G, Sun L, Xia R, Duan Y, Xu J, Yang H, et al. Clinical malaria along the China-Myanmar border, Yunnan Province, China, January 2011-August 2012. Emerg Infect Dis. 2014;20:675-8.

43. Bouma MJ. Methodological problems and amendments to demonstrate effects of temperature on the epidemiology of malaria. A new perspective on the highland epidemics in Madagascar, 1972-89. Trans R Soc Trop Med Hyg. 2003;97:133-9.

44. Kristan M, Abeku TA, Beard J, Okia M, Rapuoda B, Sang J, et al. Variations in entomological indices in relation to weather patterns and malaria incidence in East African highlands: implications for epidemic prevention and control. Malar J. 2008;7:231
45. Paaijmans KP, Blanford S, Bell AS, Blanford JI, Read AF, Thomas MB. Influence of climate on malaria transmission depends on daily temperature variation. PNAS. 2010;107:15135-9.

46. Sithiprasasna R, Linthicum KJ, Liu GJ, Jones JW, Singhasivanon P. Some entomological observations on temporal and spatial distribution of malaria vectors in three villages in northwestern Thailand using a geographic information system. Southeast Asian J Trop Med Public Health. 2003;34:505-16.

47. Ebrahimi B, Shakibi S, Foster WA. Delayed egg hatching of Anopheles gambiae (Diptera: Culicidae) pending water agitation. J Med Entomol. 2014;51:580-90.

48. Tsunoda T, Cuong TC, Dong TD, Yen NT, Le NH, Phong TV, et al. Winter refuge for Aedes aegypti and Ae. albopictus mosquitoes in Hanoi during Winter. PLoS One. 2014;9:e95606.

49. Tian HY, Bi P, Cazelles B, Zhou S, Huang SQ, Yang J, et al. How environmental conditions impact mosquito ecology and Japanese encephalitis: an eco-epidemiological approach. Environ Int. 2015;79:17-24.

50. Midekisa A, Beyene B, Mihretie A, Bayabil E, Wimberly MC. Seasonal associations of climatic drivers and malaria in the highlands of Ethiopia. Parasit Vectors. 2015;8:339.

51. Srimath-Tirumula-Peddinti RC, Neelapu NR, Sidagam N. Association of climatic variability, vector population and malarial disease in District of Visakhapatnam, India: a modeling and prediction analysis. PLoS One. 2015;10, e0128377.

\section{Submit your next manuscript to BioMed Central and take full advantage of:}

- Convenient online submission

- Thorough peer review

- No space constraints or color figure charges

- Immediate publication on acceptance

- Inclusion in PubMed, CAS, Scopus and Google Scholar

- Research which is freely available for redistribution 